\title{
Research on Building Energy Consumption and Sustainability Development in China - Heating Energy Consumption and Related Policies in North China
}

\author{
Lei $\mathrm{XU}^{1)}$ and Jian $\mathrm{ZHANG}^{2)}$ \\ ${ }^{1)}$ Dept. of Architecture, Tohoku Institute of Technology \\ 35-1 Yagiyama, Kasumicho, Taihakuku, Sendai, Miyagi, 982-8577, Japan \\ E-mail: xulei@tohtech.ac.jp \\ ${ }^{2)}$ Advanced Research Institute of Science and Engineering, Waseda University
}

(received on July 24, 2012, accepted on October 1, 2012)

\begin{abstract}
China's building energy consumption increased 2.5 times from 1996 to 2008, and it accounts for about $23 \%$ of the total energy consumption in the whole country. The energy consumption in the cities and towns in North China reaches nearly $4.5 \mathrm{EJ}$, which is about $25 \%$ of the total energy consumption in buildings. District heating system is the most popular, with the heating floor area of about 7.5 billion $\mathrm{m}^{2}$. The co-generation system and the central boiler system are often used. These days the government pays much more attention to building energy saving, and the related policies and financial support for the promotion of renewable energy resources. In many cities, some small boilers have been replaced by the ground source heat pumps. In this paper the investigation of some geothermal heat pump plants in Shenyang is also introduced.
\end{abstract}

Keywords: Building Energy Consumption, Sustainability Development, District Heating, Ground Source Heat Pump, System COP

\section{Introduction}

China's GDP increased with 9\% growth rate annually in the last ten years, and ranked the second of the world in 2010. With the quick development in economic activities and improvement of living conditions, China's building energy consumption increased 2.5 times from 1996 to 2008 . Heating is necessary in North China during winters, which leads to a growing demand for heating energy consumption. In this paper, the building energy consumption and energy policies related to the energy consumed by heating are introduced. Geothermal heat pumps are often used in North China for energy saving. The investigation of geothermal heat pump plants in Shenyang, the largest city in

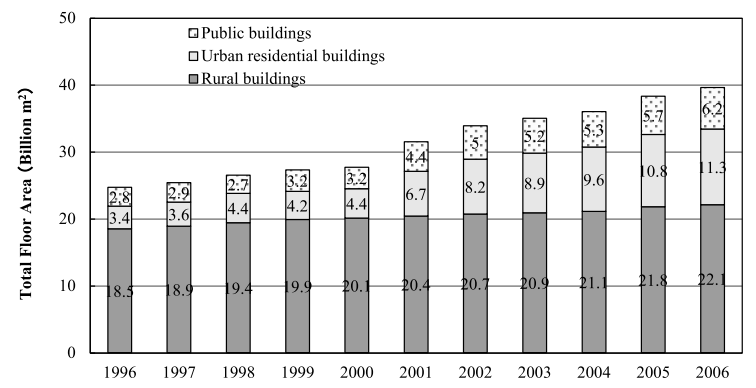

Figure 1. Increase of total floor area from 1996 to 2006
Northeast China is also introduced.

Current situation of building energy consumption in China

Figure 1 shows that the building floor area in the whole country increased from 25 billion $\mathrm{m}^{2}$ to 40 billion $\mathrm{m}^{2}$ from 1996 to 2006 (THUBERC, 2009). The construction of urban residential buildings increased the most quickly, which is nearly 4 times as much as that in 1996, with an increase of about 800 million $\mathrm{m}^{2}$ every year.

The climate characteristics in China can be divided into 5 different types illustrated in Figure 2: the Hot Summer Warm Winter Area in the south, the Warm Area in the southwest, the Hot Summer Cold Winter Area in the east, the Cold Area in the north, and the severe cold area in the northeast. According the regulation, the district heating is adopted in the urban areas located in the north of the border line during winters. Beijing, Tianjin and other provinces like Hebei, Shanxi, Inner Mongolia, Liaoning, Jilin, Heilongjiang, Shandong, Henan, Shanxi, Gansu, Qinghai, Ningxia and Xinjiang belong to this heating area.

As shown in Figure 3, the building energy consumption increased from 7.6 EJ (Exa Joule) in 1996 to 
19.2EJ in 2008 (THUBERC, 2011), which accounts for about $23 \%$ of the total energy consumption in China. Energy consumption for heating in urban residential buildings in North China increased from 2.1 EJ in 1996 to $4.5 \mathrm{EJ}$ in 2008 , which is about $25 \%$ of the total energy consumption in buildings.

The individual system, central boiler plant and cogeneration system are often used for district heating in

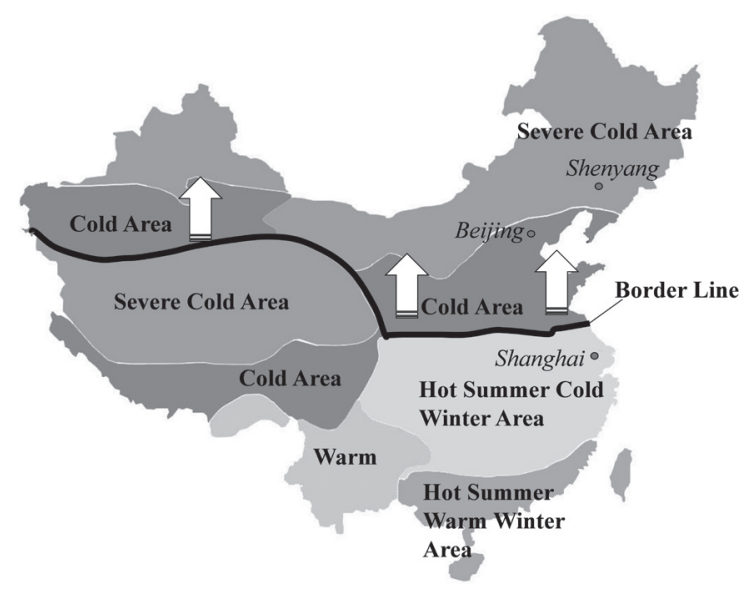

Figure 2. Climate Zone in China

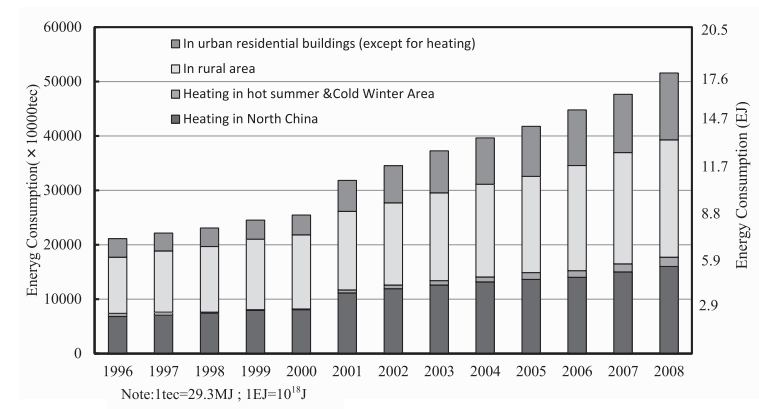

Figure 3. Building Energy Consumption in China (1996-2008)
North China. The energy consumption of the individual system is $730 \mathrm{MJ} /\left(\mathrm{m}^{2}\right.$.a) with the heating floor area of 2.3 billion $\mathrm{m}^{2}$. The central boiler plant supplies the same floor area with the co-generation system, of about 2.6 billion $\mathrm{m}^{2}$. The co-generation system consumes only $387 \mathrm{MJ} / \mathrm{m}^{2}$, while the central boiler consumes $583 \mathrm{MJ} / \mathrm{m}^{2}$ in one year (THUBERC, 2009). As the energy efficiency of the individual system is the lowest, the individual boilers have been replaced by renewable energy systems in many cities.

\section{Related policies and regulations on energy consumption}

With the growing energy demand, the Chinese government has paid more attention to energy saving in buildings. As listed in Table 1, many related policies have been carried out since 2005 (CPGPRC). One key milestone was the passage of the 2005 Renewable Energy Law approved by the Standing Committee of the National People's Congress, which promotes the application of solar energy, bioenergy and geothermal energy. In 2007, the Comprehensive Work Plan on Energy Conservation and Emission Reduction was worked out, and the energy saving rate is prescribed to be $20 \%$ and emission reduction rate of $10 \%$. In 2010 , the government decaled their financial incentive funds for energy management contracting projects, and the Ministry of Finance and the local government would give financial subsidies of about 150 Yen for the energy saving of one GJ.

China's 12th Five-Year Plan (2011-2015) was ratified by the National People's Congress (NPC) in March 2010, and the following goals related to environment and clean energy are included in this plan:

- Non-fossil fuel to account for $11.4 \%$ of primary energy consumption;

- Water consumption per unit of value-added

Table 1. Energy policies related to energy conservation prescribed by the government

\begin{tabular}{|c|c|l|}
\hline Issued Date & Issued by & Regulations related to Energy Conservation \\
\hline $2005 / 3$ & NPC & Renewable Energy Law \\
\hline $2007 / 5$ & State Council & Comprehensive Work Plan on Energy Conservation and Emission Reduction \\
\hline $2007 / 11$ & MOHURD & $\begin{array}{l}\text { Statistics Report System of Energy Consumption and Conservation in Civil Buildings } \\
\text { (Trial Implementation) }\end{array}$ \\
\hline $2007 / 12$ & MOF & $\begin{array}{l}\text { Interim Measure on Financial Incentive Funds for Heat Measuring and Energy Saving } \\
\text { Technology Development in existing building in North China }\end{array}$ \\
\hline $2008 / 7$ & MOHURD & $\begin{array}{l}\text { Technical Guideline for Heat Measuring and Energy Saving Technology Development } \\
\text { in the retrofit of existing buildings in North China }\end{array}$ \\
\hline $2008 / 10$ & MOHURD & Regulation on Energy Conservation in Civil Buildings \\
\hline $2009 / 11$ & MOHURD & $\begin{array}{l}\text { Information Statistics Reporting System for Civil Building Energy Consumption and } \\
\text { Conservation }\end{array}$ \\
\hline $2010 / 5$ & State Council & $\begin{array}{l}\text { Notice on Further Expanding Work Efforts to Ensure the Achievement of Energy } \\
\text { Conservation and Emission Reduction Targets in the 11th Five-Year Plan }\end{array}$ \\
\hline $2010 / 6$ & NDRC, MOF & $\begin{array}{l}\text { Interim Measure on Financial Incentive Funds for Energy Management Contracting } \\
\text { Projects }\end{array}$ \\
\hline
\end{tabular}

Note: NPC: National People's Congress; MOHURD: Ministry of Housing and Urban-Rural Development of P.R.C. MOF: Ministry of Finance of P.R.C.; NDRC: National Development and Reform Commission 
industrial output to be cut by $30 \%$;

- Energy consumption per unit of GDP to be cut by $16 \%$;

- Carbon dioxide emission per unit of GDP to be cut by $17 \%$;

- Forest coverage rate to rise to $21.66 \%$ and forest stock to increase by 600 million cubic meters.

Therefore, energy saving, as well as the application of renewable energy, has been promoted in the whole country. Usually heating costs can be calculated by Equation 1, which is charged by the floor area, no matter how much heat is used. In order to saving energy in heating, the reform of heat charging system has been carried out in some places for trial. Heating costs can be calculated by Equation 2, which can be divided into two parts. One is the basic rate and the other is the step meter rate.

Heating Costs $=$ Basic Rate $\times$ Floor Area

New Heating Costs $=$ Basic Rate $\times$ Floor Area + Step Meter Rate $\times$ Heat Consumption

For example heating costs in Beijing were about 24RMB (about 290Yen) per square meters for one year. According to the new system (Table 2), the basic rate has been set to be $7 \mathrm{RMB} / \mathrm{m}^{2}$ for boiler using coal, and the step meter rate was set to be about $44.45 \mathrm{RMB} / \mathrm{GJ}$ (e.g. 540Yen/GJ) in some areas for trail in last October (FZWB), which gives the incentive for energy savings in buildings and energy centers. The less heat consumption the less heat costs. Renewable energy resources have attracted a lot of attention. Many small boiler plants have been replaced by geothermal heat pumps.

Table 2. Heat charging reform in Beijing for trail

\begin{tabular}{|l|l|l|}
\hline Heat Costs & \multicolumn{2}{|c|}{ Rate } \\
\hline \multirow{3}{*}{ Basic Rate } & Coal Boiler & $\begin{array}{l}7 \mathrm{RMB} / \mathrm{m}^{2} . \mathrm{a} \\
\left(84 \mathrm{Yen} / \mathrm{m}^{2} . \mathrm{a}\right)\end{array}$ \\
\cline { 2 - 3 } & District Heating & $\begin{array}{l}12 \mathrm{RMB} / \mathrm{m}^{2} \cdot \mathrm{a} \\
\left(144 \mathrm{Yen} / \mathrm{m}^{2} . \mathrm{a}\right)\end{array}$ \\
\cline { 2 - 3 } & Gas/Oil/Electrical Boiler & $\begin{array}{l}18 \mathrm{RMB} / \mathrm{m}^{2} . \mathrm{a} \\
\left(220 \mathrm{Yen} / \mathrm{m}^{2} \cdot \mathrm{a}\right)\end{array}$ \\
\hline Step Meter Rate & 44.45RMB/GJ (540Yen/GJ) \\
\hline
\end{tabular}

\section{Application of geothermal heat pump}

Although the first geothermal system was installed in 1995, the total heating area had reached 80 million $\mathrm{m}^{2}$ by the end of 2007 . Figure 4 shows that it had increased at a surprising speed from 1998 to 2007.

As to the types of geothermal heat pump, the ground water source has the biggest share, of about $42 \%$, and the ground source heat pump is the next, of about $32 \%$. Waste water source is the smallest, of about $12 \%(\mathrm{Xu}, \mathrm{W}$.). The application of geothermal heat pump has been popularized all over the county, and about $80 \%$ is concentrated in Beijing, Shandong Province and Liaoning Province. The geothermal heat pump industry in China is a 7.2 Billion RMB (850 Billion Yen) worthy market per year.

\section{Investigation of geothermal heat pump plant in Shenyang}

According to investigation of some energy centers in Shenyang, the capital of Liaoning Province, the ground water source heat pump shown in Figure 5 is often used. Using the waters from 60 meters depth, the heat efficiency of the whole system is quite good.

As the calcium hardness of the hot water is $139 \mathrm{mg} / 1$ to $343 \mathrm{mg} / 1$ in some plants, scaling occurs in the condenser of the heat pump, and the cleaning of the pipes is important. Together with the following optimization on the operation in the plants, the system COP

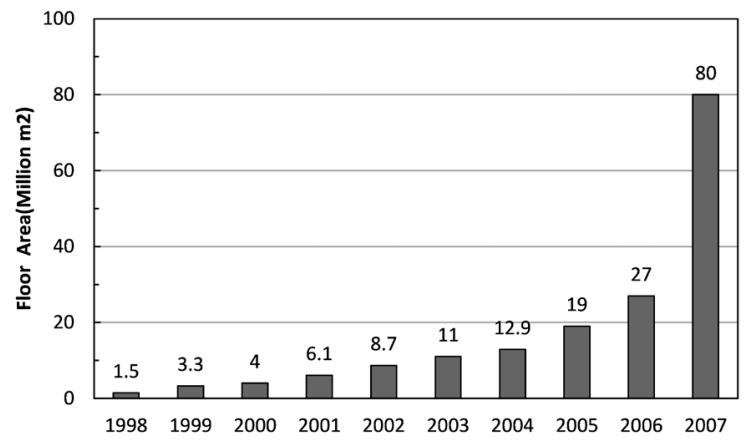

Figure 4. Increase of geothermal heat pump system in China

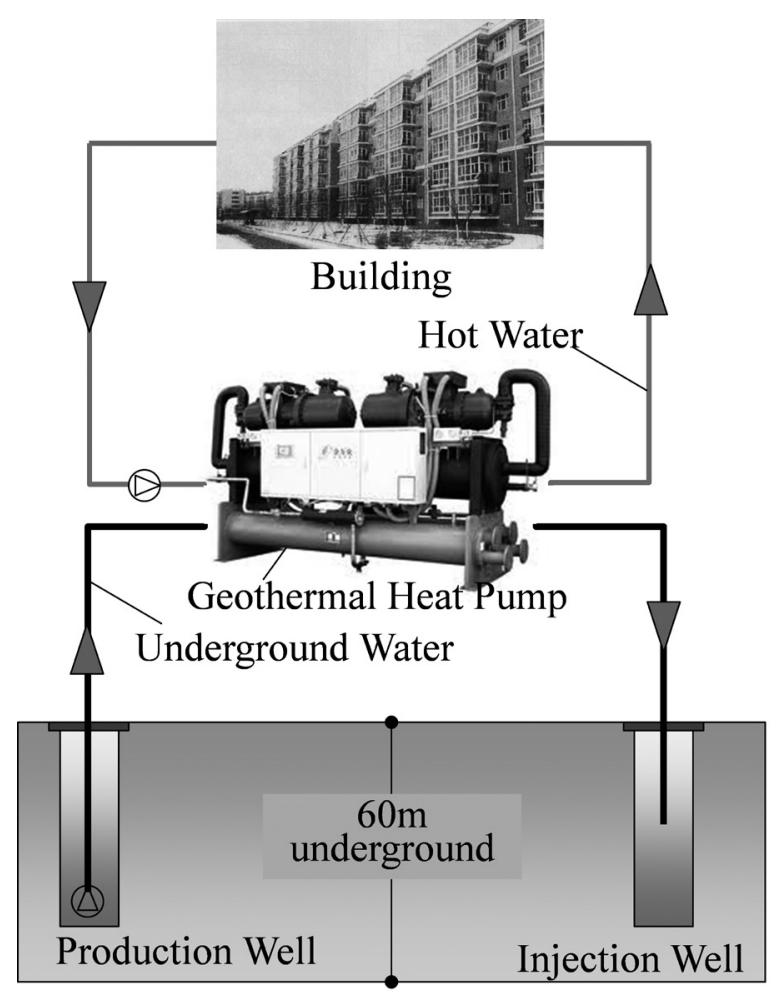

Figure 5. Geothermal HP investigated in Shenyang 


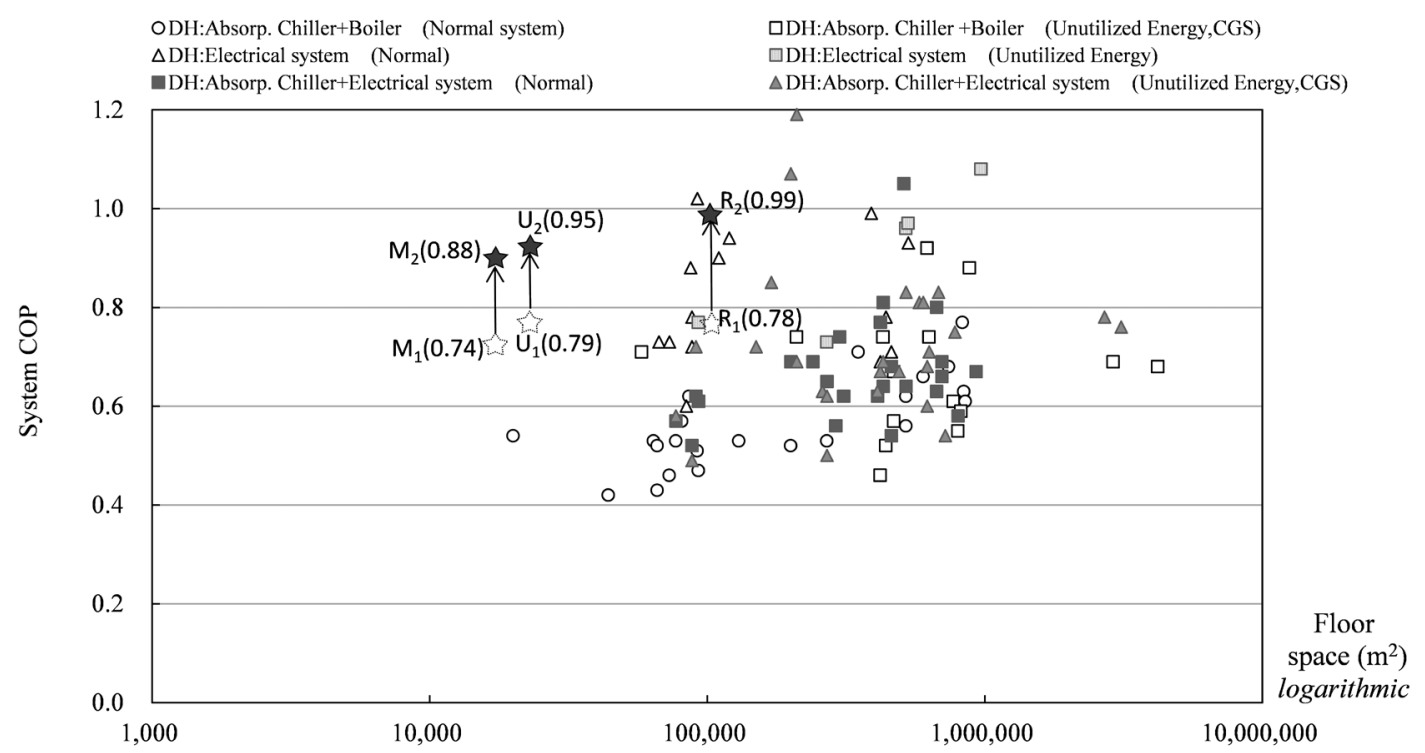

Figure 6. Comparison with district heating plants in Japan

including the electricity consumed by the pumps, increases from 0.74 to 0.88 in the Plant of middle school M, and 0.79 to 0.95 in the Plant of university $U$, and 0.78 to 0.99 in the Plant of housing complex R, which brings about an improvement in efficiency of $20 \%$ to $27 \%$ (JETRO). With the optimization of the operation in plants, the energy efficiency can be improved greatly, such as:

- Optimization of the operation of pumps;

- Decrease the supply temperature of hot water;

- Installation of volume control valve.

Figure 6 shows the efficiency of district heating plants in Japan. Although the highest efficiency is about 1.2 , the average is only about 0.69 , which is lower than the figures of Shenyang. It shows that the efficiency of geothermal heat pump plants in Shenyang is higher.

\section{Conclusion}

China's building energy consumption increased about 2.5 times in recent 12 years, which accounts for about $23 \%$ of the total in the whole country. The energy consumption for heating in the northern cities reaches nearly $4.5 \mathrm{EJ}$, which is about $25 \%$ of the total energy consumption in buildings. The energy efficiency of the individual boiler is the lowest. These days the government has issued many policies on building energy saving, and offered the financial support for the promotion of renewable energy resources. And the reform of heat charging system has been carried out in some places for trial which will be helpful for energy savings in heating. In many cities, small boilers have been replaced by the ground source heat pump systems. According to the investigation in Shenyang, the energy efficiency of geothermal heat pump plants is about 0.74 to 0.78 , which is higher than that in the district heating plants in Japan. With the optimization of the operation conditions in the plants, the system COP can be improved by $20 \%$ to $27 \%$, which will lead to more energy savings.

\section{Reference}

1 ) THUBERC.2009. Annual Report on China Building Energy Efficiency 2009, China Architecture \& Building Press: 6-7.

2 ) THUBERC. 2011. Annual Report on China Building Energy Efficiency 2011, China Architecture \& Building Press: 2-3.

3 ) CPGPRC. Laws \& Regulations, http://www.gov. cn/zfwj/index.htm. Accessed Nov. 15, 2011.

4 ) FZWB. The Reform of Heat Charging System will be Firstly Carried Out in Beijing for Trial, http:// news.sina.com.cn/c/2010-09-27/135318166753s. shtml. Accessed Nov. 20, 2011.

5 ) Xu, W. 2008. Report on China Ground-Source Heat Pump 2008, China Architecture \& Building Press.

6 ) JETRO. 2010. Report on the Promotion of Energy Conservation- Performance Verification on the heating system in North China (Shenyang) Part $1: 15$. 